\title{
Early life stages of development of the red porgy Pagrus pagrus (Pisces, Sparidae) in captivity, Argentina
}

\author{
Laura Machinandiarena', Mónica Müller ${ }^{2}$ \& Andrea López ${ }^{3}$ \\ Instituto Nacional de Investigación y Desarrollo Pesquero (INIDEP) \\ PO Box 175, 7600 Mar del Plata, Argentina \\ E-mail: ${ }^{1}$ lauram@inidep.edu.ar, ${ }^{2}$ mmuller@inidep.edu.ar, ${ }^{3}$ alopez@inidep.edu.ar
}

\begin{abstract}
The early life history, from egg to juvenile, of red porgy Pagrus pagrus, in captivity is described. Yolk larvae were hatched 50 hours after fertilization, at $18^{\circ} \mathrm{C}$ water temperature. The opening of the mouth took place between the third and fourth day after hatching, corresponding to 2.6-2.8 $\mathrm{mm}$ notochordal length. The transformation stage began at $9 \mathrm{~mm}$ standard length, approximately 40 days after hatching. The appearance of the fins favored the displacement of pelagic larvae towards the bottom, acquiring their demersal habit during the juvenile stage.
\end{abstract}

Key words: Pagrus pagrus, egg, larval development.

\section{Desarrollo de los estadios iniciales del besugo Pagrus pagrus (Pisces, Sparidae) en cautiverio, Argentina}

RESUMEN. Se describen los estadios iniciales, desde huevo hasta juvenil, del besugo Pagrus pagrus obtenidos en cautiverio. Las larvas vitelinas eclosionan 50 horas posteriores a la fertilización, a una temperatura de $18^{\circ} \mathrm{C}$. La apertura de la boca se produce entre el tercer y cuarto día posteriores a la eclosión, correspondiendo a 2,6-2,8 $\mathrm{mm}$ de longitud de la notocorda. La etapa de transformación comienza en larvas de $9 \mathrm{~mm}$ de longitud estándar y 40 días, aproximadamente. La formación de las aletas favorece el desplazamiento de las larvas pelágicas hacia el fondo, adquiriendo hábito demersal durante el estadio juvenil.

Palabras claves: Pagrus pagrus, huevos, desarrollo de larvas.

\section{INTRODUCTION}

The red porgy Pagrus pagrus, family Sparidae, has been intensely fished off Argentine by commercial fleet during the 80's and early 90's, given their high quality and price in the international markets. This intense fishing determined the diminution of the captures in more than a fifty percent since 1985 . This situation was confirmed by the fisheries statistics (Secretaría de Agricultura, Ganadería y Pesca, 1994; Redes, 1999). In 1994, the Instituto Nacional de Investigación y Desarrollo Pesquero (INIDEP) began the marine fish culture research, to develop a culture technology for the commercial production of red porgy.

Numerous studies related with the ontogeny of sparids as Pagrus major (Fukuhara, 1985, 1991), $P$. auratus (Kingsford \& Atkinson, 1994) and P. pagrus from the Mediterranean Sea (Ranzi, 1931-56) or in waters of Greece (Kentouri et al., 1992, have been carried out. In Argentine there was only one report and this corresponded to Ciechomski \& Weiss (1973), who described eggs, yolk sac and preflexion larvae of red porgy.

The objective of this paper is to describe the early stages of red porgy Pagrus pagrus in captivity, from eggs to juveniles 70 days after hatching (DAH).

\section{MATERIALS AND METHODS}

\section{Eggs}

In October 1998 began the natural spawning of the broodstock in aquarium conditions. The spawning took place mainly at dusk and the eggs were gathered in collectors from the overflowing water, early in the morning. Fertilized eggs (floating) were sorted, counted and placed in round tanks of 400 liters, at 
140 per liter. In the tanks, the water temperature was controlled at $18 \pm 1^{\circ} \mathrm{C}$, with smooth ventilation (Aristizábal et al., 1997a).

\section{Larvae}

After hatching, the larvae were reared in tanks of 500 liters, at an average density of 70 larvae per liter. It was used a closed circuit of seawater with UV filters and smooth ventilation, under constant illumination (800 lux) (Aristizábal et al., 1997a).

\section{Larval feeding}

Larval feeding consisted of a modification of the scheme presented by Watanabe \& Kiron (1996). For the first $10 \mathrm{DAH}$, the Nannochloropsis oculata green water system was used. Larvae were fed with "ultra-small" Brachionus sp. at a density of 5-15 rotifers per milliliter, from 3 until $12 \mathrm{DAH}$ (Aristizábal et al., 1997b). Subsequently, Artemia franciscana was introduced into the diet from 9 until $35 \mathrm{DAH}$, at a density of 25-30 nauplii per milliliter. From day 25 also A. franciscana metanauplii and balanced dry food Nippai (Larval Feed $\mathrm{N}^{\circ} 1$ and 2) and INVE (NRG $\mathrm{N}^{\circ} 3$ and 4) were added into the diet. Gradually, the provision of metanauplii was diminished, and from $65 \mathrm{DAH}$ on, only balanced dry food was provided.

\section{Egg and larval development}

Age, in egg stages, corresponds to the hours after fertilization; and during larval and juvenile stages, corresponds to the days after hatching. Observations of external morphology, pigmentation and measurements were made in live specimens, anaesthetized in MS 222 (Sandoz). The measurements were carried out with an ocular micrometer under stereoscopic microscope (Wild M8). The different stages were classified in yolksac larva, larva (preflexion, flexion, postflexion), transformation larva and juvenile (Kendall et al., 1984).

\section{Pigmentation}

Although living specimens were densely pigmented with xanthophores (yellow chromatophores), only melanophores (black chromatophores) were illustrated, since they remain after preservation.

\section{Development of the mouth}

The opening of the mouth was calculated according to Shirota (1970), considering a $90^{\circ}$ angle limited by the jaws during the feeding.

\section{Morphometrics}

The following measurements were made: notochordal length (LN): tip of the snout to tip of notochord, in small larvae before notochordal flexion; standard length (SL): tip of snout to base of caudal fin (posterior margin of the hypural plates), on larger larvae in which flexion of notochord has occurred; body depth (BD): vertical height of body, measured at the anus, and head length (HL): tip of snout to the posterior margin of the cleithrum.

\section{Meristics}

In the smaller larvae, total myomeres were counted. Vertebrae, rays and spines were counted on cleared and stained specimens, according to the techniques described by Potthoff (1984), and Taylor \& Van Dyke (1985).

\section{RESULTS}

\section{Morphology and pigmentation}

Eggs

Red porgy eggs were spherical with a diameter of 890 to $930 \mu \mathrm{m}$. The single yellow and transparent oil globule ranged from 180 to $200 \mu \mathrm{m}$ in diameter, and it was unpigmented during the early stages of development. The chorion was unsculptured and the perivitelline space was narrow. An initial stage of four blastomeres is observed in Fig. 1a. Living embryos of 25 hours after fertilization (Fig. 1b) covered more than a half of the egg perimeter and the Kuppfer vesicle was growing at the caudal bud. In that stage, the oil globule was unpigmented. Some body myomeres, the auditory sacs and nonpigmented eyes were distinguished. Small melanophores were observed in the dorsal part of the head. Near hatching time, the embryo reached $2 / 3$ of the egg diameter and the Kuppfer vesicle disappeared (Fig. 1c). The oil globule acquired pigmentation, and the embryos were pigmented with xantophores and punctuate melanophores.

Yolk sac larvae $(\mathrm{NL}=1.92-3.04 \mathrm{~mm})$

Hatching began 50 hours after fertilization at $18^{\circ} \mathrm{C}$. Newly hatched larvae were elongated, the yolk sac was large and the only oil globule was located at the end of the yolk mass. The yolk sac volume, 
$\mathbf{a}$

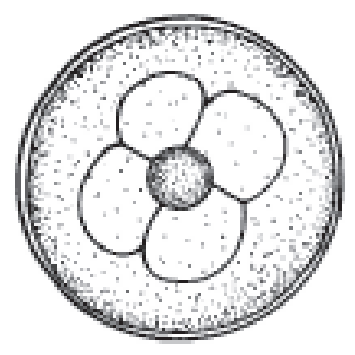

b

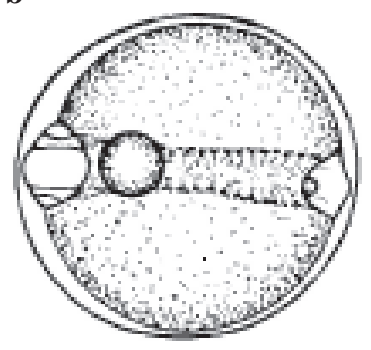

c

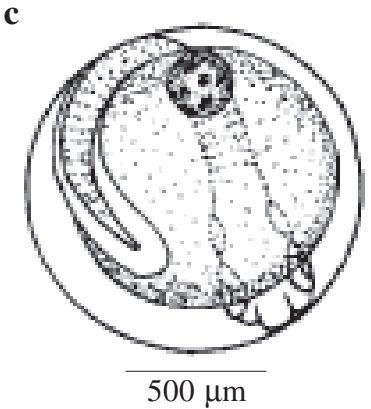

Figure 1. Pagrus pagrus eggs at different stages of embryogenesis. a) Initial stage of 4 blastomeres, b) Embryo of 25 hours after fertilisation, c) Near hatching embryo.

Figura 1. Diferentes estadios de desarrollo de huevos de Pagrus pagrus. a) Estadio inicial de 4 blastómeros, b) Embrión de 25 horas posteriores a la fertilización, c) Embrión próximo a la eclosión.

assuming its form like a spheroid (Blaxter \& Hempel, 1963), oscillated between 0.12 and 0.08 $\mathrm{mm}^{3}$, decreasing in volume as the larval length increased. The eyes began to pigment. Small melanophores were observed in ventral and dorsal midline, in the yolk sac and in the oil globule. Pigmentation increased with length, mainly in the ventral midline, between the anus and the end of the notochord. Small punctuate and stellate melanophores were observed above the gut. Xanthophores were prominent in all the body, mainly in the head and round the tail (Fig. 2a). The opening of the mouth began between the third and fourth DAH (2.6 to $2.8 \mathrm{~mm} \mathrm{NL}$ ). Simultaneously, the eyes completed their pigmentation. During this stage, the larvae were buoyant due to their yolk sac. Larvae remained obliquely near the surface, with the head pointing downwards. At the end of this stage, the pectoral fin buds began to develop.

Preflexion larvae $(\mathrm{NL}=3.00-4.48 \mathrm{~mm})$

Larvae began their exogenous feeding three or four DAH. Preflexion larvae were elongated and body depth increased with gut development. The urinary vesicle was observed. Pigmentation increased around the cephalic region and in the ventral midline. A stellate melanophore was observed on the tip of the snout. Some prominent stellate melanophores were also distinguished in the gut region (Fig. 2b). An occipital spine developed 10 DAH (3.50 $\mathrm{mm} \mathrm{NL}$ ), that remained during all the larval stage. Several preopercular spines began to appear. Xanthophores diminished as larvae grew, remaining only in the occipital spine and opercular region. Stellate melanophores were observed on the snout. A single melanophore was present near the ventral tip of the notochord (Fig. 2c). Preflexion larvae were pelagic. During this stage, larvae frequently browsed the walls of the tanks. The preflexion larvae stage extended between the 4th to 17 th DAH.

\section{Larvae in flexion ( $\mathrm{SL}=4.40-6.41 \mathrm{~mm}$ )}

These elongated larvae were more pigmented over the trunk region. Some caudal fin rays and hypurals began to appear in the finfold lobe. Larvae in flexion still had remnants of the finfold, and it was gradually lost as dorsal, anal and caudal fins developed. In this stage, 22 to 25 myomeres could be quantified. A stellate melanophore developed at the base of the pectoral fin. Small melanophores were serially arranged along the ventral midline (Fig. 2d). Notochord reached a flexion of $45^{\circ}$ during swimming. Larvae in flexion stage extended between 18th to 29th DAH.

Postflexion larvae $(\mathrm{SL}=5.66-9.27 \mathrm{~mm})$

Larvae were more pigmented. The head profile became rounded and the body depth increased. The dorsal, anal, caudal and pectoral fin shapes were present. The pelvic fins rays began to develop. The pigmentation increased in the cephalic region, and some melanophores were present on the maxillaries. A dense pigment patch on lateral surface of caudal peduncle, and small melanophores were observed in some pelvic rays. Two opercular spines began to appear. Dorsal, anal, caudal and pelvic fins reached their full complement of rays during this stage (Fig. 2e). The postflexion larvae period extended between the 23rd to 37th DAH. 
a

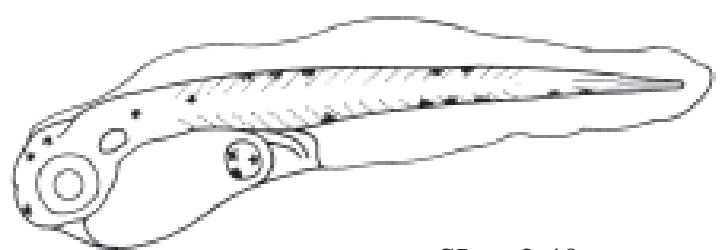

$\mathrm{SL}=2.40 \mathrm{~mm}$

Age $=6 \mathrm{HAH}$

c

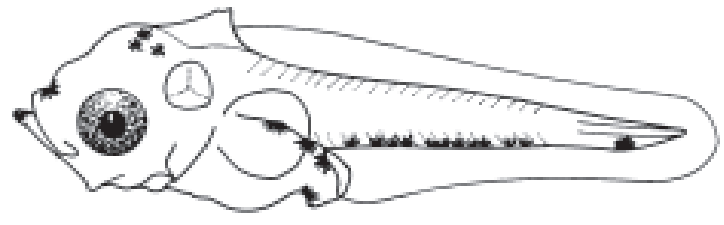

$\mathrm{SL}=4.32 \mathrm{~mm}$

Age $=14$ DAH

e

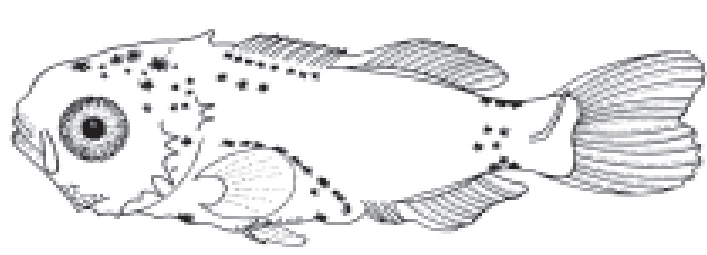

$\mathrm{SL}=7.75 \mathrm{~mm}$

Age $=35 \mathrm{DAH}$

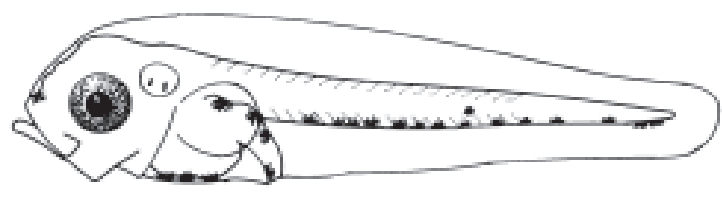

$\mathrm{SL}=3.20 \mathrm{~mm}$

Age $=7$ DAH

d

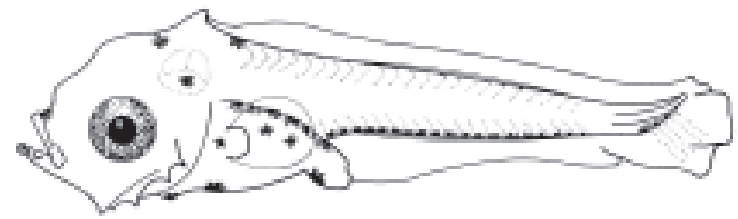

$\mathrm{SL}=4.40 \mathrm{~mm}$

Age $=18 \mathrm{DAH}$

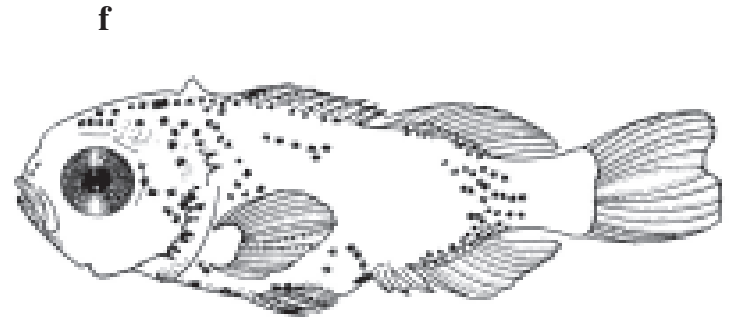

$\mathrm{SL}=9.50 \mathrm{~mm}$

Age $=43 \mathrm{DAH}$

g

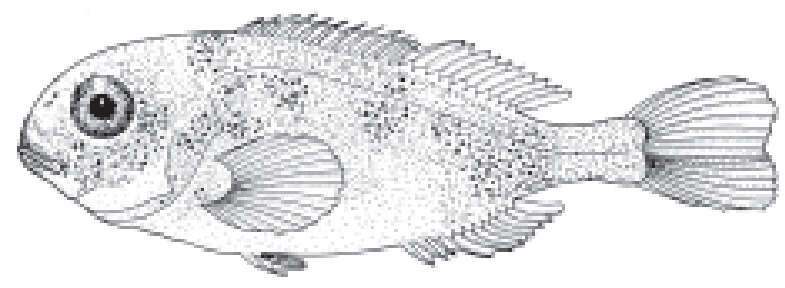

$\mathrm{SL}=33 \mathrm{~mm}$

Age $=70 \mathrm{DAH}$

Figure 2. Pagrus pagrus larval development. a) yolk sac larva, b) and c) preflexion larva, d) larva in flexion, e) postflexion larva, f) transformation larva, g) juvenile. HAH: hours after hatching, DAH: days after hatching. Figura 2. Desarrollo larval de Pagrus pagrus. a) larva vitelina, b) y c) larva preflexionada, d) larva en flexión, e) larva postflexionada, f) larva en transformación, g) juvenil. HAH: horas posteriores a la eclosión, DAH: días posteriores a la eclosión. 
Transformation stage $(\mathrm{SL}=9.50-13.00$ $\mathrm{mm}$ )

The transformation stage corresponded to a period in which the larval aspect was gradually lost. The bodies were opaque. As larvae grew, pigmentation intensified over the trunk region. The head profile was convex and their spines were reduced in size and number. Punctuate and stellate melanophores in the trunk were observed. Small melanophores in the developing dorsal and pelvic fins were present, associated to spines. The dense pigment patch on the lateral surface of caudal peduncle and melanophores along dorsal and anal fin bases were observed. Caudal fin shape became forked and pectoral fin reached their full complement (Fig. 2f). The transformation stage began at $9 \mathrm{~mm} \mathrm{SL}$, approximately $40 \mathrm{DAH}$.

\section{Juveniles}

This stage was characterized by the acquisition of the complete fin-ray complements and squamation. Juveniles were morphologically similar to the adults. As juveniles grew, ctenoid scales covered all the body. The mouth was terminal and only caniniform teeth were visualized in both jaws. The pigmentation pattern was uniform, constituted by punctuate and small stellate melanophores. In addition, some vertical lateral bands were distinguished (Fig. 2g). Although juveniles were pelagic, they began to migrate towards the bottom at approximately the 51st DAH, to search for food.

\section{Age-length relationship}

Yolk sac phase was the briefest period. Within the larval period, preflexion larval stage was the most extended, reaching $5 \mathrm{~mm}$ SL. Transformation stage extended from 9 to $19 \mathrm{~mm}$ SL approximately. By $51 \mathrm{DAH}$, all specimens were juveniles longer than 13 mm SL (Fig. 3).

\section{Development of the mouth}

The mouth opened at 2.80 to $3.40 \mathrm{~mm}$ SL larvae, between the third and fourth $\mathrm{DAH}$, at the end of yolk sac larva stage (Figs. $4 a$ and $4 b$ ). When the oral cavity opened, the mouth size oscillated between 140 to $340 \mathrm{~mm}$ and gradually increased as larvae grew.

\section{Morphometrics}

Body depth ranged from 5 to $9 \%$ NL for newly hatched larvae. In juveniles increased more than $30 \%$ SL. Head length increased throughout larval development from about $20 \%$ NL to more than $30 \%$ $\mathrm{SL}$ in larvae in flexion. Juveniles had head lengths ranging from 33 to $37 \%$ SL (Table 1).

\section{Meristics and fin development}

All examined specimens had 22 to 26 myomeres. The definitive number of vertebrae (22 to 23 ) was observed in 7-8 $\mathrm{mm} \mathrm{SL}$ larvae, $35 \mathrm{DAH}$

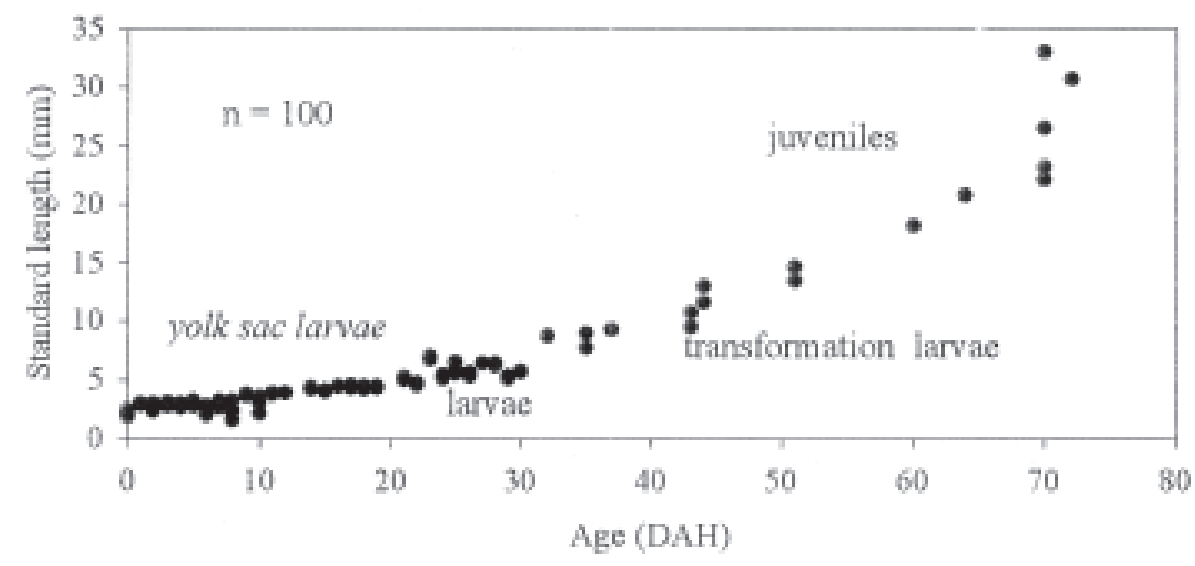

Figure 3. Relationship between length of larvae and juveniles (SL) and number of days after hatching (DAH). n = sample size.

Figura 3. Relación entre el largo estándar de larvas y juveniles (SL) y el número de días posteriores a la eclosión (DAH). $n$ = tamaño de muestra. 
approximately. In newly hatched larvae, finfold was the first distinguished fin. Pectoral buds appeared in yolk sac or preflexion larvae, during the third DAH. Dorsal, anal and caudal fin buds were distinguished in 5.50-6.50 mm SL larvae. Finfold was gradually lost as the other fins developed. Unpaired fins reached their full complement of rays (dorsal XI-XIII, 10-11; anal II-III, 6-8; caudal 1417) in flexion and postflexion larvae longer than 6 $\mathrm{mm}$ SL. Pectoral and ventral fins were the last ones in completing their definitive number of rays (13-16 and I, 5, respectively), in specimens longer than $9 \mathrm{~mm}$ SL.

\section{DISCUSSION}

In our study, egg and oil globule diameters (Table 2) were quite similar to those obtained by artificial fecundity of red porgy captured in Argentine shelf and described by Ciechomski \& Weiss (1973). According to Kentouri et al. (1992), the egg size from Mediterranean Sea red porgy, obtained by natural spawning, were lightly bigger. The range of egg sizes could change according to the period of observations within the spawning season and the different considered areas.

The hatching process, at $18^{\circ} \mathrm{C}$ water temperature, began approximately 50 hours after fertilization, as observed by Kuronuma \& Fukusho (1984) for $P$.
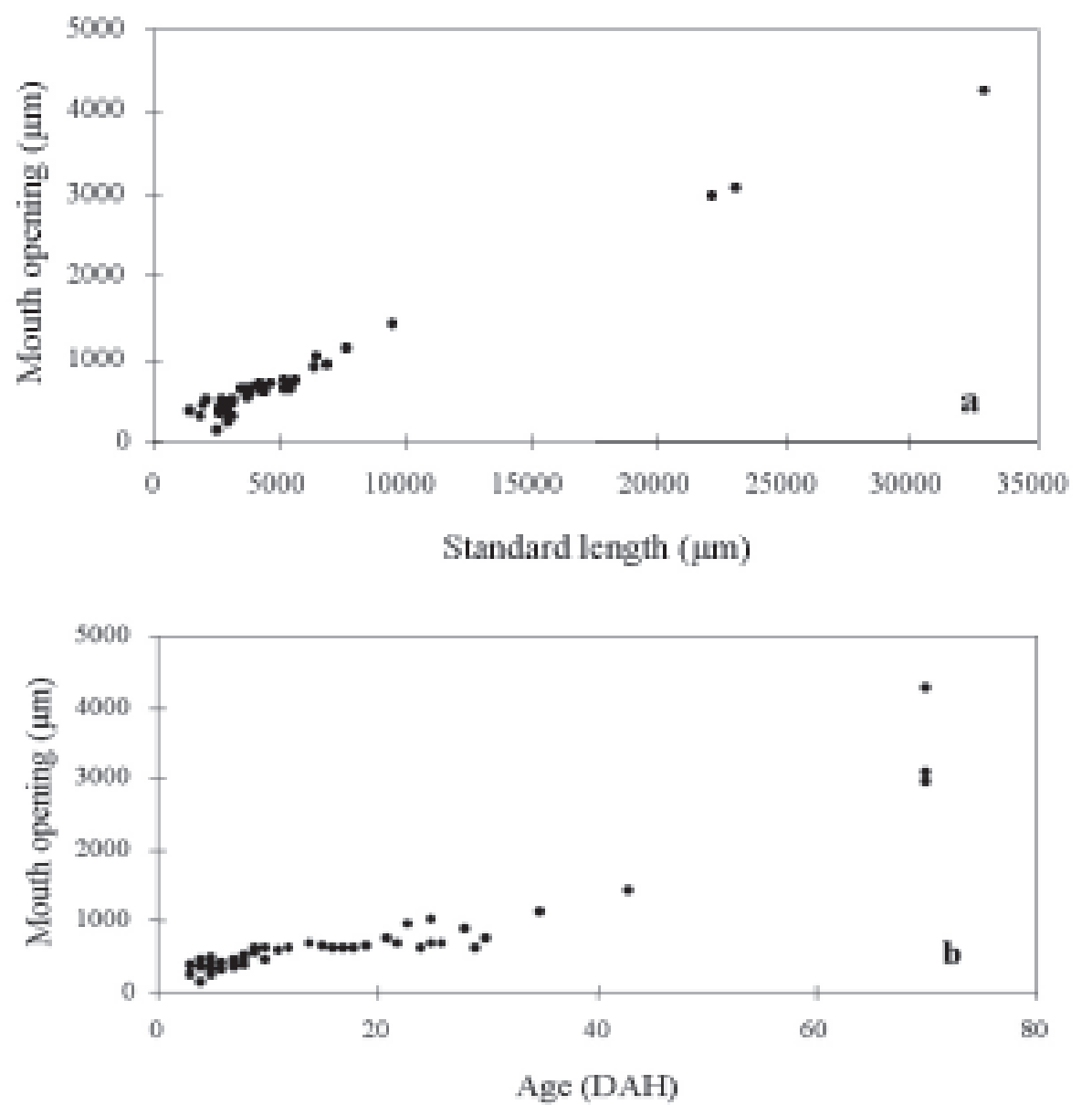

Figure 4. Relationship between a) mouth opening and size, b) mouth opening and age of Pagrus pagrus larvae and juveniles. DAH: days after hatching.

Figura 4. Relación entre a) apertura de la boca y talla, b) apertura de la boca y edad de larvas y juveniles de Pagrus pagrus. DAH: días posteriores a la eclosión. 
Table 1. Body depth (BD) and head length (HL) in relation to notochordal length (NL) or standard length (SL). The rank of values is observed between parenthesis. In the inferior line, the average value is observed. Tabla 1. Altura del cuerpo (BD) y largo de la cabeza (HL) en relación con el largo de la notocorda (NL). Entre paréntesis se presentan los valores observados. En la línea inferior, el valor promedio.

\begin{tabular}{|ccccc|}
\hline Development stage & Age (days) & NL or SL $(\boldsymbol{\mu m})$ & BD/SL & HL/SL \\
\hline Yolk sac larvae & $(0-4)$ & $(1920-3040)$ & $(0.05-0.09)$ & $(0.17-0.20)$ \\
& 2 & 2673.33 & 0.07 & 0.18 \\
Preflexion larvae & $(3-19)$ & $(3000-4480)$ & $(0.05-0.11)$ & $(0.16-0.35)$ \\
& 8.50 & 3201.43 & 0.08 & 0.24 \\
Larvae in flexion & $(18-29)$ & $(4440-6414)$ & $(0.10-0.17)$ & $(0.26-0.43)$ \\
& 24.13 & 5309.38 & 0.12 & 0.30 \\
Postflexion larvae & $(23-37)$ & $(5664-9270)$ & $(0.15-0.25)$ & $(0.31-0.34)$ \\
& 30.33 & 7455.67 & 0.20 & 0.32 \\
Transformation larvae & $(43-44)$ & $(9500-13001)$ & 0.30 & 0.33 \\
Juveniles* & 43.67 & 11340.33 & & $(0.33-0.37)$ \\
& $(51-70)$ & $(13390-33000)$ & $(0.29-0.37)$ & 0.35 \\
\hline
\end{tabular}

* This stage is longer. The proportions observed correspond to the specimens considered in this study.

Table 2. Egg and oil globule diameters in different sparids species.

Tabla 2. Diámetro de los huevos y gotas oleosas en diferentes especies de espáridos.

\begin{tabular}{|cccc|}
\hline Species & Egg diameter $(\boldsymbol{\mu m})$ & Oil globule diameter $(\boldsymbol{\mu m})$ & Author \\
\hline Pagrus pagrus & $810-880$ & $176-194$ & Ciechomski \& Weiss $(1973)$ \\
& $980-1025$ & $250 \pm 7$ & Kentouri et al. $(1992)$ \\
& $890-930$ & $180-200$ & This paper \\
Pagrus major & $660-1030$ & 250 & Fukuhara $(1985)$ \\
Sparus aurata & $940-1050$ & - & Estévez (1991) \\
& $900-1100$ & - & Pillay (1995) \\
& $1000-1030$ & $220-250$ & Méndez (1994) \\
Archosargus rhomboidalis & $800-940$ & $210-260$ & Houde \& Potthoff $(1976)$ \\
\hline
\end{tabular}

Table 3. Hatching time of Pagrus pagrus, in previous experiences.

Tabla 3. Tiempo de eclosión de Pagrus pagrus, en experiencias previas.

\begin{tabular}{|cccc|}
\hline Period & Broodstock & Water temperature $\left(\mathbf{\pm} \mathbf{1}^{\circ} \mathbf{C}\right)$ & Hours after hatching \\
\hline '95-'96 & captivity wild* & 20 & 48 \\
'96-'97 & captivity & 18 & $50-52$ \\
'97-'98 & wild* & 16 & $58-60$ \\
\hline
\end{tabular}

* Fertilisation and embryonic development in captivity. 
major. Bedier et al. (1984) noted, in Sparus aurata, that hatching occurred 70 hours after fertilization at $16^{\circ} \mathrm{C}$. Hatching periods presented in this work and unpublished data (Table 3), were coincident with the ranges established by other authors.

Newly hatched sparid larvae are generally similar in size when hatching, presence of melanophores in the oil globule and in the ventral midline were observed (Houde \& Potthoff, 1976). In our study, the exogenous feeding began by the end of the stage of yolk sac larvae, approximately four days after hatching. Simultaneously, the eyes completed their pigmentation. As larvae grew up, pigmentation increased and xantophores diminished their presence. Ciechomski \& Weiss (1973) reported similar descriptions of yolk sac and early preflexion larvae morphology and pigmentation.

The mouth opened, between the third and fourth day after hatching at $18^{\circ} \mathrm{C}$ water temperature. Ciechomski \& Weiss (1973) observed that the mouth opened sixty hours after hatching at higher water temperature. Early larvae were characterized by small mouth. The mouth sizes detected in larvae longer than $5 \mathrm{~mm} \mathrm{SL}$ were coincident with the observations of Kuronuma \& Fukusho (1984).

The beginning of the notochordal flexion occurred at $4 \mathrm{~mm}$ SL, which agrees with the findings of Houde \& Potthoff (1976) in the Sparidae Archosargus rhomboidalis. The transformation period began at $9 \mathrm{~mm}$ SL (40 days after hatching). Coincidentally, Fukuhara (1991) observed in another Sparidae, P. major, similar length proportions during the different development stages.

Preopercular and opercular spines were gradually lost by the end of the larval period. The occipital spine disappeared in the beginning of the juvenile stage. The disposition of the mentioned spines agreed with the observations of Ranzi (193156).

The proportions of body depth and head length based on the standard length reached $33 \%$ and $34 \%$ in early juveniles, respectively. The observed proportions are similar to those ones found by Houde \& Pothoff (1976) in early juveniles of $A$. rhomboidalis. In addition, the head acquires blunt dorsal profile as larvae grew.

At the end of the larval period, 22-23 vertebrae can be quantified, in concordance with the value registered by Ranzi (1931-56). The sequence of development of fins was coincident with the observation of Houde \& Potthoff (1976), in A. rhomboidalis. The definitive numbers of spines and rays were similar to those reported by Inada (1984) and Mendez (1994) in the adults of P. pagrus.

Early larvae had scarce own mobility and remain obliquely in the surface layer of the water column, with the head pointing downwards. Yolk sac larvae swimming followed the pattern described by Foscarini (1988) in P. major. At the beginning of exogenous feeding, mobility increased, and larvae moved in surface and mid water, mainly to capture living food. The appearance of the fins was coincident with the displacement of pelagic larvae towards the bottom, acquiring their demersal habits during the juvenile stage. Early juveniles fed on artificial food in both surface and bottom of the tank, since they moved actively through the entire water column.

\section{ACKNOWLEDGEMENTS}

We would like to express our gratitude to Gabriel Bambill del Laboratorio de Maricultura del Instituto Nacional de Investigación y Desarrollo Pesquero (INIDEP), Argentina, for his invaluable assistance. We also thank Eddie Aristizábal and the anonymous reviewers for their valuable comments on the draft. INIDEP Contribution $\mathrm{N}^{\circ} 1244$.

\section{REFERENCES}

Aristizábal, E.O., M.I. Müller, G. Bambill, A.V. López, M. Sabatini, M. Costagliola, S. Incorvaia, A.Vega, J.C. Carrizo \& E. Manca. 1997a. Producción de alimento vivo y cría de besugo. Período 1995-1996. Inf. Téc. Int. DNIINIDEP, 83/1997, 92 pp.

Aristizábal, E.O., M.I. Müller, A.V. López, G.A. Bambill \& M. Sabatini. 1997b. Producción de microalgas y rotíferos y su aplicación en piscicultura marina. Inf. Téc. Int. DNI-INIDEP, 59/ 1997, 16 pp.

Bedier, E., B. Chatain, D. Coves \& M. Weppe. 1984. L'Aquaculture de bar et des Sparidés. INRA Publ., Paris, pp. 223-236.

Blaxter, J.H.S. \& G. Hempel. 1963. The influence of egg size on herring larvae (Clupea harengus L.). J. Cons. int. Explor. Mer, 28(2): 211-240. 
Ciechomski, J.D. de \& G. Weiss. 1973. Desove y desarrollo embrionario y larval del besugo, Pagrus pagrus (Linne) en el Mar Argentino (Pisces, Sparidae). Physis, Secc. A, 32(85): 481-487.

Estévez, A. 1991. Fecundación y desarrollo embrionario. Reproducción de peces cultivados $\mathrm{N}^{\circ} 7$. Canselleria de Pesca, Marisqueo e Acuicultura, Xunta de Galicia, 17 pp.

Foscarini, R. 1988. A review: intensive farming procedures for red sea bream (Pagrus major) in Japan. Aquaculture, 72: 191-246.

Fukuhara, O. 1985. Functional morphology and behavior of early life stages of red sea bream. Bull. Japan. Soc. Sci. Fish., 51(5): 731-743.

Fukuhara, O. 1991. Size and age at transformation in red sea bream, Pagrus major, reared in the laboratory. Aquaculture, 95: 117-124.

Houde, E.D. \& T. Potthoff. 1976. Egg and larval development of the sea bream Archosargus rhomboidalis (Linnaeus): Pisces, Sparidae. Bull. Mar. Sci., 26(4): 506-529.

Inada, T. 1986. Sparidae. In: I. Nakamura (ed.). Important fishes trawled off Patagonia. JAMARC, pp. 218-219.

Kendall, A.W., E.H. Ahlstrom \& H.G. Moser. 1984. Early life history stages of fishes and their characters. In: G. Moser, W.J. Richards, D.M. Cohen, M.P. Fahay, A.W. Kendall \& S.L. Richardson (eds.). Ontogeny and systematics of fishes. Amer. Soc. Ichthyol. Herpet. Spec. Publ., 1: 11-22.

Kentouri, M., G. Koumoundouros, P. Divanach \& A. Sterioti. 1992. The embryonic development of red porgy (Pagrus pagrus) and of common dentex (Dentex dentex) in Crete. Proceedings of the XXXIII C.I.E.S.M. Congress, 12-17 October, Trieste, 3 pp.

Kingsford, M.J. \& M.H. Atkinson. 1994. Increments in otoliths and scales: how they relate to the age and early development of reared and wild larval and juvenile Pagrus auratus (Sparidae). Aust. J. Freshwater Res., 45: 1007-1021.

Kuronuma, K. \& K. Fukusho. 1984. Rearing of marine fish larvae in Japan. IDRC, Ottawa, 109 pp.

Mendez, E. 1994. Data monitoringin I.M.B.C., an application in Broodstock Management. Institute of Marine Biology, Aquaculture Department, Crete, 20 pp.

Pillay, T.V.R. 1995. Seabasses and seabreams. Aquaculture, principles and practices. Fishing News Books, Oxford, 575 pp.

Potthoff, T. 1984. Clearing and staining techniques. In: G. Moser, W.J. Richards, D.M. Cohen, M.P. Fahay, A.W. Kendall \& S.L. Richardson (eds.). Ontogeny and systematics of fishes. Amer. Soc. Ichthyol. Herpet. Spec. Publ., 1: 35-37.

Ranzi, S. 1931-56. Sparidae. In: Uova, larvae e stadi giovanili di Teleostei. Fauna e Flora del Golfo di Napoli, 38: 332-382.

Redes. 1999. Diez años de captura. Revista Redes de la Industria Pesquera Argentina, 12(106): 32-45.

Secretaría de Agricultura, Ganadería y Pesca. 1994. Guía Pesquera Argentina. Masindian Consultores S.A., Buenos Aires, pp. 109-111.

Shirota, A. 1970. Studies on the mouth size of fish larvae. Bull. Japan. Soc. Sci. Fish., 36(4): 353-368.

Taylor, W.R. \& G.C. Van Dyke. 1985. Revised procedures for staining and clearing small fishes and other vertebrates for bone and cartilage study. Cybium, 9(2): 107-119.

Watanabe, T. \& V. Kiron. 1996. Red sea bream (Pagrus major). In: N. Bromage \& R. Roberts (eds.). Broodstock management and egg and larval quality. Blackwell Science, New York, pp. 398413. 